\section{Economic and environmental impacts of the corn grain ethanol industry on the United States agricultural sector}

\author{
J.A. Larson, B.C. English, D.G. De La Torre Ugarte, R.J. Menard, C.M. Hellwinckel, and T.O. West
}

\begin{abstract}
This study evaluated the impacts of increased ethanol production from corn starch on agricultural land use and the environment in the United States. The Policy Analysis System simulation model was used to simulate alternative ethanol production scenarios for 2007 through 2016. Results indicate that increased corn ethanol production had a positive effect on net farm income and economic wellbeing of the US agricultural sector. In addition, government payments to farmers were reduced because of higher commodity prices and enhanced net farm income. Results also indicate that if Conservation Reserve Program land was converted to crop production in response to higher demand for ethanol in the simulation, individual farmers planted more land in crops, including corn. With a larger total US land area in crops due to individual farmer cropping choices, total US crop output rose, which decreased crop prices and aggregate net farm income relative to the scenario where increased ethanol production happened without Conservation Reserve Program land. Substantial shifts in land use occurred with corn area expanding throughout the United States, especially in the traditional corn-growing area of the midcontinent region. Production of other crops, such as soybeans and cotton, shifted out of traditional growing areas to accommodate increased corn production. Fertilizer and chemical usage also increased. When conservation tillage adoption was assumed to remain at 2007 levels for the 10-year period, regional tillage intensity, soil erosion, and fossil fuel-based carbon emissions increased, while soil carbon stocks decreased as a result of increased corn production. However, the simulation demonstrated that additional adoption of conservation tillage above 2007 levels mitigated the adverse effects of increased corn production on soil erosion and net carbon emissions to the atmosphere.
\end{abstract}

Key words: carbon emissions_ carbon sequestration — land use — net farm income- soil erosion-tillage intensity

Research suggests that agricultural land-use changes from increased ethanol production using corn (Zea mays L.) starch could increase soil erosion, fertilizer and pesticide pollution, and greenhouse gas emissions (Nash 2007; Searchinger et al. 2008; Donner and Kucharik 2008). This study evaluated the potential aggregate and regional agricultural land use and environmental impacts of rising corn ethanol production on the US agricultural sector using an integrated modeling approach. Ethanol production in the United States jumped from 6.0 million $\mathrm{kL} \mathrm{y}^{-1}$ (1.6

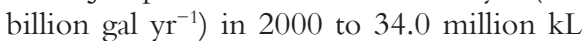
$\mathrm{y}^{-1}$ (9 billion gal $\mathrm{yr}^{-1}$ ) in 2008 (Renewable Fuels Association 2009a). Thus far, almost

all of the ethanol produced in the United States is made from corn starch (US DOE EIA 2008). The expansion of production has been fueled by rising prices for petroleum and gasoline, a $\$ 0.13 \mathrm{~L}^{-1}\left(\$ 0.51 \mathrm{gal}^{-1}\right)$ credit that is provided by the US government to those who blend ethanol with gasoline before selling it to gas stations, and the substitution of ethanol for methyl tertiary butyl ether as an oxygenate in gasoline (Novack and Henderson 2007). Ethanol production was initially concentrated in the midcontinent region of the United States but has expanded from 17 states having ethanol plants in 1999 to 26 states having plants in 2008 (Renewable Fuels Association 2009b).
As part of the US government's growing focus on reducing dependence on petroleum and encouraging the production of fuels from renewable sources, the Energy Independence and Security Act of 2007 called for the production of 135.8 million $\mathrm{kL} \mathrm{y}^{-1}$ (36 billion gal $\mathrm{yr}^{-1}$ ) of renewable fuels by 2022 (US Congress 2007). The act established a level of 56.6 million $\mathrm{kL} \mathrm{y}^{-1}$ (15 billion gal $\mathrm{yr}^{-1}$ ) of ethanol from corn starch by 2015 and at least 79.2 million $\mathrm{kL} \mathrm{y}^{-1}$ (21 billion gal $\mathrm{yr}^{-1}$ ) of cellulosic ethanol and other renewable fuels such as ethanol from sugarcane (Saccharum officinarum) and biodiesel by 2022 . Notwithstanding the 2007 legislative initiative to increase the production of renewable fuels from sources other than corn starch, the production of ethanol from corn grain is expected to rise significantly over the next several years in response to legislative mandates and tight energy market supply and demand conditions (Sexton et al. 2008).

In the short run, a rise in the demand for ethanol feedstock from corn starch increases the price of corn, makes corn production more profitable, and gives farmers an incentive to plant more corn (Cassman et al. 2006). The economic impacts of expanded ethanol production on farmers and rural areas have generally been positive, with increased net farm income (NFI) for farmers and enhanced rural economic activity from the establishment of more ethanol refineries (Miranowski et al. 2008). However, the increased demand for renewable fuels and the government incentives provided for ethanol production have the potential to impact land use and land resources differently in regions across the United States (Nelson et al. 2009).

Changes in cropping patterns with increased corn ethanol production have the potential to impact soil erosion regionally.
James Larson, is an associate professor, Burton English is a professor, and Jamey Menard is a research associate in the Department of Agricultural and Resource Economics, The University of Tennessee, Knoxville, Tennessee. Daniel De La Torre Ugarte is a professor, and Chad Hellwinckel is a research assistant professor in the Agricultural Policy Analysis Center, The University of Tennessee, Knoxville, Tennessee. Tris West is a research scientist at the Joint Global Change Research Institute, Pacific Northwest National Laboratory, College Park, Maryland, and adjunct faculty in the Biosystems Engineering and Soil Science Department, The University of Tennessee, Knoxville, Tennessee. 
Water-induced soil erosion is influenced by tillage intensity, choice of crop, landscape, precipitation, and other factors (Wischmeier and Smith 1965; Wischmeier and Smith 1978). Adoption of conservation tillage practices, such as no-tillage, varies by crop (CTIC 2005) and is influenced by a number of factors, such as the profitability of the practice for a given crop, the growing environment, and by government conservation compliance provisions (Sandretto and Payne 2006).

Fertilizer and pesticide usage also differs by crop and is an indicator of potential fertilizer and pesticide pollution if more inputs are used for one crop relative to another crop (Sandretto and Payne 2006; Daberkow and Wang 2006). About $40 \%$ of all commercial fertilizer used in the United States is consumed in corn production (Daberkow and Wang 2006). The US Geological Survey estimates that about $90 \%$ of nitrogen $(\mathrm{N})$ and $75 \%$ of phosphorus $(\mathrm{P})$ pollution in agriculture are from nonpoint sources related to crop production (USGS 1999).

Fossil fuel consumption and carbon dioxide $\left(\mathrm{CO}_{2}\right)$ emissions can increase or decrease with changes in cropland management that influence the amounts of inputs used such as fuel, fertilizer, pesticides, and the mix of tillage practices (West et al. 2008; Nelson et al. 2009). On-farm $\mathrm{CO}_{2}$ emissions result from the combustion of fossil fuels that are directly related to crop production. Off-farm $\mathrm{CO}_{2}$ emissions emanate from the use of fossil fuels for the manufacturing and transportation of inputs such as fertilizers, pesticides, and seeds used in crop production. No-tillage requires less fossil fuel consumption and produces less $\mathrm{CO}_{2}$ emissions than conventional tillage (Nelson et al. 2009). Estimates of fossil fuel consumption and $\mathrm{CO}_{2}$ emissions have been made for some agricultural inputs in the United States (West and Marland 2002; Lal 2004; Adler et al. 2007). Aggregate annual $\mathrm{CO}_{2}$ emissions from crop production in the United States have been estimated to be between 103 trillion g CO $\mathrm{y}^{-1}$ (113.5 million th $\left.\mathrm{CO}_{2} \mathrm{yr}^{-1}\right)(\mathrm{CCSP} 2007)$ and 111 trillion $\mathrm{g} \mathrm{CO}_{2} \mathrm{y}^{-1}$ (122.4 million th $\mathrm{CO}_{2}$ $\mathrm{yr}^{-1}$ ) (USDA 2004). However, the estimates of $\mathrm{CO}_{2}$ emissions from US crop production are based on national averages of crop inputs or on total fossil fuel consumption in the agricultural sector and do not account for regional variability in cropping practices (Nelson et al. 2009).
Changes in cropland use and tillage intensity can also influence the accumulation rate of soil organic carbon (SOC) and thus the amount of $\mathrm{CO}_{2}$ sequestered in agricultural soils (Lal et al. 1998; West and Post 2002; Marland et al. 2003; Sperow et al. 2003; Ogle et al.2009). In addition, US government farm programs, such as the Conservation Reserve Program (CRP) and acreage set-aside provisions in pre-1996 farm bills, have been shown to have positively influenced SOC sequestration (Sperow 2007; West et al. 2008; Nelson et al. 2009). Sperow (2007) estimated the amount and marginal cost of SOC sequestration from setting aside highly erodible land in the United States. For 1997, he estimated that total SOC sequestered on the 21.9 million ha (54.1 million ac) where corn, cotton (Gossypium hirsutum L.), sorghum (Sorghum bicolor L.), soybean (Glycine $\max$ L.), wheat (Tricum aestivum L.), or fallow was planted amounted to more than 10 trillion g carbon (C) (11 million tn C). The weighted average marginal cost of sequestered SOC was estimated to be $\$ 288 \mathrm{Mg}^{-1} \mathrm{C}\left(\$ 261 \mathrm{tn}^{-1} \mathrm{C}\right)$. West et al. (2008) analyzed changes in SOC associated with changes in tillage practices and land use in the CRP within the midcontinent region of the United States. They estimated that a SOC accumulation of 70.3 trillion g C (77.5 million tn C) occurred in this region between 1991 and 2000 .

Estimates are needed on a more spatially specific cropland basis of changes in agricultural land use, water-induced soil erosion, input usage, and $\mathrm{C}$ fluxes associated with rising corn ethanol production. Information about the potential national and regional changes in agricultural land use and environmental impacts of increasing ethanol production will contribute to future policy discussion about renewable energy production and agricultural production. Thus, the objective of this study was to evaluate the potential land use and environmental impacts of rising corn ethanol production on a national and regional basis for the US agricultural sector.

\section{Materials and Methods}

The Policy Analysis System (POLYSYS) agricultural policy simulation model (De La Torre Ugarte et al. 1998) was used to evaluate potential shifts in US crop area due to changes in crop prices and crop net revenues caused by increased demand for corn starch as a feedstock for ethanol. The potential impacts of land-use changes on fertilizer and chemical usage, water-induced soil erosion, $\mathrm{CO}_{2}$ emissions, and the accumulation of SOC in agricultural soils were also simulated using POLYSYS. Land-use changes and environmental impacts are reported in aggregate for the United States and by Crop Reporting District (CRD) and Farm Resource Region as defined by the USDA (figure 1) (USDA ERS 2000). The economic and environmental modules in POLYSYS and the corn starch ethanol production and conservation tillage adoption scenarios simulated using the model are each described in turn.

Economic Module. POLYSYS is structured as a system of interdependent modules of crop supply for 305 CRDs in the United States, national livestock supply, national crop and livestock demands, and national agricultural income.The eight major crops simulated using POLYSYS were barley (Hordeum vulgare L.), corn, cotton, oats (Avena sativa L.), rice (Oryza sativa), sorghum, soybeans, and wheat. Hay was also simulated in the model. The POLYSYS simulations were anchored to a published USDA Economic Research Service (ERS) agricultural baseline projection for the agricultural sector. POLYSYS simulated deviations from the baseline for alternative US ethanol production scenarios. The baseline is a 10 -year forecast for the agricultural sector that USDA produces annually. In this study, the 2007 to 2016 baseline (USDA ERS 2007) was used for all crop prices, input prices, yields, and supplies. Thus, the assumptions about the macroeconomic environment, technological changes influencing yields, government programs such as the CRP, and other economic parameters used in the analysis were from the 2007 baseline.

The 2002 Census of Agriculture from the USDA National Agricultural Statistics Service (NASS) indicate that 380 million ha (938 million ac) of land in the United States were used for agricultural production (USDA NASS 2004). Of that area, 176 million ha (434 million ac) were classified as cropland, and 160 million ha (395 million ac) were classified as pastureland or rangeland. In the 2007 baseline (USDA ERS 2007), the average total US cropland of 124 million ha (307 million ac) was assumed available for the production of the eight major crops and hay over the 2007 to 2016 period. The remainder of the 176 million ha in cropland was in minor crops, fruits, vegetables, and CRP.The land base for crop production in POLYSYS was expanded 


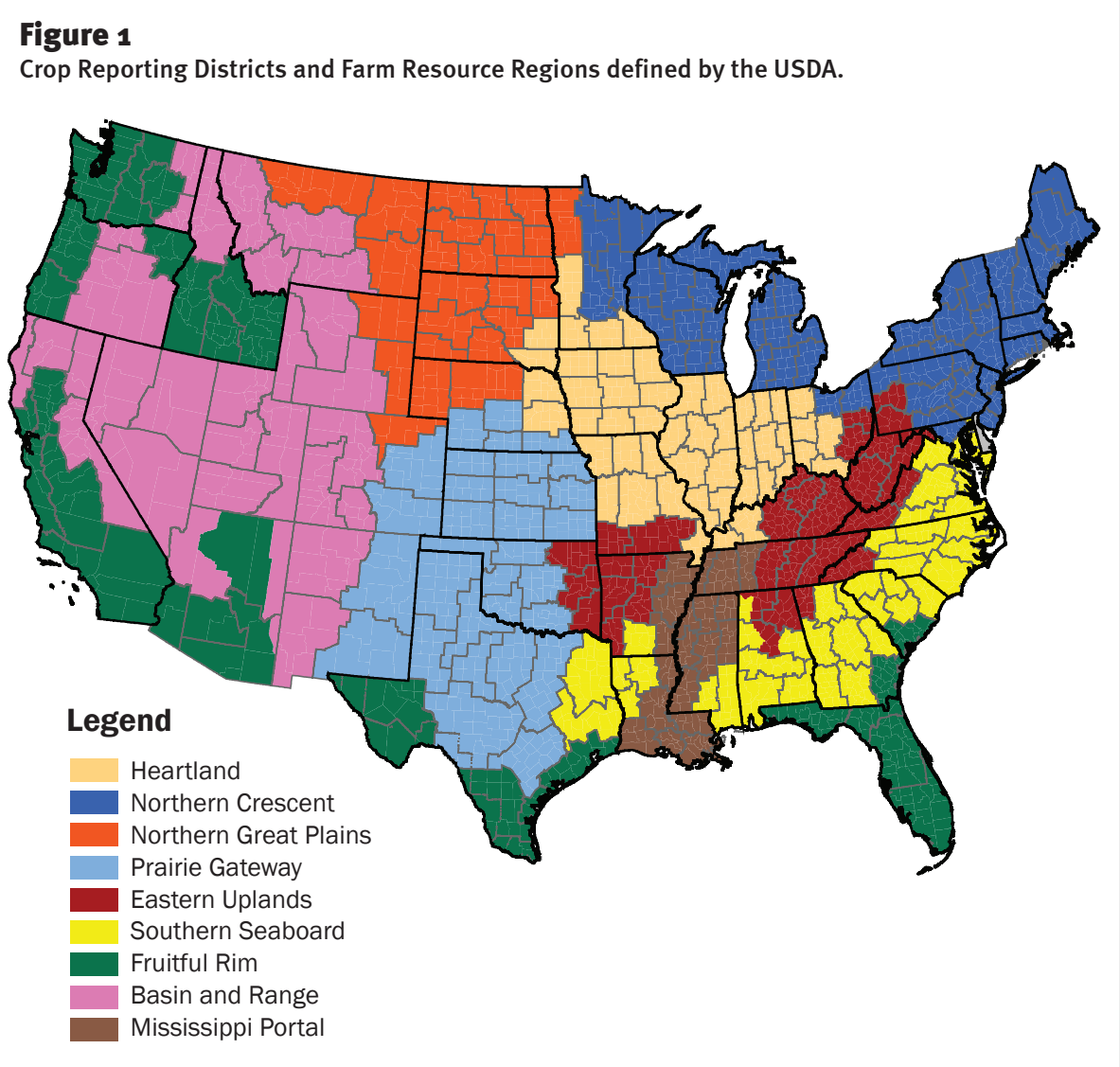

to include CRP land but not pastureland for this analysis. Pastureland use is closely tied to regional livestock inventories, which are slow to respond to commodity price rises. For this reason, potential pastureland conversions were not included in this analysis.

The crop supply module simulates crop net revenues and land allocations using crop yields from the 2007 USDA agricultural baseline, costs of production by tillage practice (conventional, reduced, and no-tillage), and land allocations to the various crops in each CRD. Data from the Conservation Technology Information Center (CTIC) provided information on the area of major crop types using different tillage practices, including conventional, reduced, and conservation tillage (CTIC 2007). These three tillage practices are defined, respectively, as leaving less than $15 \%$ of the ground covered by crop residue, between $15 \%$ to $30 \%$ ground cover, and greater than 30\% ground cover (CTIC 2004). Conservation tillage encompasses tillage practices such as mulch, ridge, and no-tillage. Mulch and ridge tillage were combined into the reduced tillage category. Conventional and no-tillage were maintained as separate categories.
Estimated planted area by crop and by CRD from POLYSYS solutions was multiplied by the tillage proportions estimated from county-level CTIC data for each CRD to determine crop area planted using either conventional, reduced, or no-tillage production practices. Regional baseline crop area was anchored to the national 2007 baseline (USDA ERS 2007), which was disaggregated to a regional level based on historical crop production and supply patterns. Once the total area available for crop production in each CRD was determined, the supply module allocated land area to competing crops using a linear programming model that maximized expected net revenues using the cost of production for each crop, projected crop yields from the baseline (USDA ERS 2007), and the previous year simulated crop prices. Allocation rules in the programming model based on historical trends in adoption limited the crop area that could switch in one year from production of one crop to another in each CRD (De La Torre Ugarte et al.2003). These allocation rules simulated the historically inelastic (unresponsive) nature of agricultural supply to changes in crop prices.

Costs of production for each crop in the model were determined using the Agricultural Policy Analysis Center Agricultural Budgeting System (Slinsky et al. 1996). Operating and ownership costs under different tillage practices for each crop in each CRD region were estimated for the simulation. Operation budgets include labor time, machinery use, and all input quantities. Budgeted costs were estimated using American Society of Agricultural Engineers standards for fuel quantities and labor time and the American Agricultural Economics Association standards for all input costs (ASAE 1999; AAEA 1998). The enterprise budgets in POLYSYS did not explicitly model crop rotations, but the flexibility constraints in the supply model were used to keep land-use changes in balance with the existing crop rotations and practices (De La Torre Ugarte et al. 2003).

The crop demand module estimated national-level demand quantities and prices using own-price and cross-price elasticities and changes in baseline (USDA ERS 2007) prices. Crop utilization was estimated for domestic demand (food, feed, and industrial uses), exports, and stock carryovers. The stock carryover equation for each crop balanced crop supply and demand in the simulation. Demand quantities were estimated as a function of own-price and cross-price elasticities and selected nonprice variables, such as livestock production. Crop prices were estimated using price flexibilities, and stock carryovers were estimated as a residual element. The income module used information from the crop supply, crop demand, and livestock modules to estimate cash receipts, production expenses, government outlays, net revenues, and realized NFI.

The livestock module, an integrated version of the USDA ERS econometric livestock model (Weimar and Stillman 1990), interacted with the crop supply and demand modules to estimate livestock production, feed use, and market prices for livestock. Livestock production levels in the simulation were a function of lagged livestock and feed own and cross prices, as well as the baseline levels (USDA ERS 2007) and exogenously determined variables, such as livestock exports. The livestock sector was linked to the supply and demand modules through the feed grain component. Livestock quantities affected feed grain demand and price, and feed grain prices and supply affected livestock production. Exports and imports of livestock products were exogenous to the model. 
Distillers' dried grains (DDG) as a derivative product from ethanol production was integrated into POLYSYS to model how DDG quantity and price affected the final market equilibrium in the simulation. Because DDG is a derivative product of corn grain, the market price of DDG was calculated as a function of corn price using methods described by English et al. (2006). The amount of DDG assumed available for use by animals was constrained in POLYSYS by nutritional limits on consumption of DDG by ruminant and nonruminant animals. The limits established for this study were 30\% for beef production and $10 \%$ for poultry, pork, and dairy production (Weigel et al. 1997).

Environmental Module. Fertilizer and chemical expenditures are the proxy for changes in the quantities of fertilizers and chemicals applied on crops due to increased corn ethanol production. Prices of chemicals and fertilizers in each year of the simulation were set at levels in the baseline (USDA ERS 2007). Thus, changes in fertilizer and chemical expenditures were due to changes in input quantities, given that input prices were kept at baseline levels in each year of the simulation for each ethanol production scenario evaluated in the analysis. Fertilizer and chemical expenditures (expressed in 2007 dollars) were estimated using crop supply module budgets and by multiplying either the fertilizer (N, P, and potassium $[\mathrm{K}]$ ) or chemical expenditures by the land area for a given crop and region. The expenditures calculated in the analysis were a weighted average of the tillage system employed in the analysis for a specific CRD.

Changes in water-induced soil erosion (sheet and rill) incorporate computed levels of erosion for cropland and CRP land using the Universal Soil Loss Equation (USLE) (Wischmeier and Smith 1965; Wischmeier and Smith 1978). The 1997 and 2003 National Resources Inventory datasets from the USDA Natural Resources Conservation Service (USDA NRCS 2007a) and the countylevel tillage database from the CTIC (2007) were used to develop the USLE estimates for POLYSYS. Sheet and rill erosion $\left(\mathrm{Mg} \mathrm{ha} \mathrm{h}^{-1}\right)$ for each CRD were estimated using

$\mathrm{USLE}_{W}=\sum_{x y y} \sum_{x, y} R_{x, y} \times K_{x, y} \times L_{x, y} \times S_{x, y} \times P_{x, y, z} \times M_{x, y, z} \times A_{u, x, y, z}$

where $w$ is CRD, $x$ is land type ( $1=$ cropland, 2 = pastureland, and 3 = CRP land), $y$ is crop grown, $z$ is tillage method $(1=$ conventional tillage, 2 reduced tillage, and 3 = no-tillage), $R$ is a rainfall and runoff factor, $K$ is a soil erodability factor, $L$ is a slope length factor, $S$ is a slope steepness factor, $P$ is a crop support practice factor, $M$ is a land cover and management factor, and $A$ is total available land area. The letter $C$ is typically used to signify the land cover and management factor in the USLE. However, to avoid confusion with carbon, the letter $M$ is used to signify the land cover and management factor in the USLE in this paper. The advantage of the USLE (Wischmeier and Smith 1965; Wischmeier and Smith 1978) over the Revised Universal Soil Loss Equation (Renard et al. 1997) and Modified Universal Soil Loss Equation (Williams and Berndt 1977) models for this application is the simplicity of the USLE and the availability of data to implement the model for all regions of the continental United States examined in the study.

Estimated average $R, K, L, S$, and $P$ factors for each CRD based on the 2003 National Resources Inventory data were from the USDA Natural Resources Conservation (NRCS) (According to J. Goebel, Senior Statistician, USDA NRCS, April and June, 2007). The $M$ factor was from the 1997 National Resources Inventory reflecting cropland tillage practice by location. Estimated crop area for each CRD region from the POLYSYS crop supply solutions were multiplied by the tillage proportions for that region to determine the land area planted using conventional, reduced, and notillage practices. These estimates were then multiplied by the $R, K, L, S, P$, and $M$ factors to estimate gross sheet and rill erosion levels.

The changes in sheet and rill erosion estimated for each CRD using equation 1 were then weighted to the 105 US Geological Survey four-digit subregional hydrological units (USDA NRCS 2007b), adjusted to county boundaries, using USDA NASS crop production data as weights (USDA NASS 2007). The weighted soil erosion data were used in the Micro Oriented Sediment Simulator (MOSS) to estimate aggregate soil erosion $(\mathrm{Mg})$ nationally and in each CRD (Alexander and English 1988).

The direct and indirect $\mathrm{C}$ emissions and SOC sequestered in agricultural soils were estimated from changes in cropping activities associated with each ethanol production scenario. Direct $\mathrm{C}$ emissions include fuel use on farms and the $\mathrm{C}$ equivalent emis- sions for field decomposition of ammonia and lime. Indirect (embodied) C emissions encompass the inputs used in the processing, manufacturing, and transportation of seed, fertilizer, and chemicals applied to crops. Carbon emissions for each ethanol scenario were calculated using methods and estimated coefficients from the $\mathrm{C}$ lifecycle literature (West and Marland 2002; Marland et al. 2003; Nelson et al. 2009). The estimated coefficients and the quantities of fuel and inputs in the supply module crop budgets in POLYSYS were used to calculate total C emissions for each crop in each CRD. The estimates do not incorporate $\mathrm{C}$ emissions from fossil fuels that are being diplaced by corn ethanol, nor do they include C emissions associated with transportation of the feedstock or the transportation of ethanol following its production.

In addition, the SOC sequestered in agricultural soils for each crop and tillage practice was estimated using methods outlined by West et al. (2008). Soil organic carbon sequestered was calculated using

$\operatorname{SOCS}_{w}=\sum_{x y} \sum_{y} \operatorname{SOCB}_{w, y} \times \Delta_{y, z} \times A_{w, x, y, z}$

where SOCS is soil organic carbon sequestered $\left(\mathrm{Mg} \mathrm{ha}{ }^{-1}\right)$ in CRD $w$ for crop $y$ and tillage practice $z, S O C B$ is the base $C$ level in CRD $w$ for crop $y\left(\mathrm{Mg} \mathrm{ha}^{-1}\right)$, and $\Delta$ is the annual change in SOC for crop $y$ and tillage practice $z$. This analysis was completed using National Land Cover Data (Vogelmann et al. 2001) and STATSGO soils data (USDA NRCS 1994). The National Land Cover Data was available for the conterminous United States and represented 21 land cover/ use classes. For this analysis, all model crops were represented as subclasses defined as row crops, small grains, and pasture. Estimates of SOC change at $30 \times 30 \mathrm{~m}(98.4 \mathrm{ft}$ by $98.4 \mathrm{ft})$ resolution, commensurate with the National Land Cover Data land cover, were weighted for each CRD by the relative area of each crop category. This methodology provided crop-specific estimates of SOC change.

Estimates for the annual change in SOC $(\Delta)$ were from West and Post (2002). In their study, Carbon Management Response curves (West et al. 2004) were estimated for every major crop within the United States. The rate of SOC sequestration varies annually until a new steady state is reached. In POLYSYS, linear approximations of Carbon Management Response curves were applied 
to the crops modeled in POLYSYS. The resulting annual estimates of SOC sequestered were multiplied by crop area for each tillage practice to arrive at an estimate of total SOC sequestered by CRD.

Ethanol Production Scenarios. Several US ethanol production scenarios between 2007 and 2016 were simulated for the analysis. The 2007 baseline (USDA ERS 2007) forecasts that ethanol output will rise from 32.5 million $\mathrm{kL} \mathrm{y}^{-1}$ (8.6 billion gal $\mathrm{yr}^{-1}$ ) in 2007

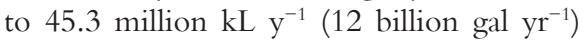
by 2016 . Changes in land use and selected environmental indicators from the baseline were evaluated for $32.5,60.4$, and 67.9 million $\mathrm{kL} \mathrm{y}^{-1}\left(8.6,16\right.$, and 18 billion gal $\left.\mathrm{yr}^{-1}\right)$ ethanol by 2016. The 32.5 million $\mathrm{kL} \mathrm{y}^{-1}$ ethanol in 2016 scenario was the same level of ethanol production for year 2007 of the baseline (USDA ERS 2007). The 32.5 million $\mathrm{kL} \mathrm{y}^{-1}$ ethanol in 2016 scenario assumed that no growth takes place in US ethanol production between 2007 and 2016 and provided a convenient point for evaluating changes in selected land use and environmental indicators with increased ethanol output. The baseline (USDA ERS 2007) assumed that land area enrolled in the CRP decline with high crop prices early on and then gradually rise to its legislated maximum of 15.9 million ha (39.2 million ac) by 2016 in response to higher CRP rental rates. The potential impacts of CRP land area coming back into crop production above levels forecasted in the baseline because of increased demand for ethanol were simulated for the 67.9 million $\mathrm{kL} \mathrm{y}^{-1}$ ethanol in 2016 scenario. Results from these scenarios were compared with the 45.3 million $\mathrm{kL} \mathrm{y}^{-1}$ ethanol in 2016 scenario in the baseline to illustrate how various ethanol industry output expansion paths might influence the agricultural sector. For all ethanol scenarios, starch from corn grain was the assumed feedstock for ethanol production. The rate of conversion of corn grain to ethanol was assumed to linearly increase from $0.401 \mathrm{~kg}^{-1}\left(2.7 \mathrm{gal} \mathrm{bu}^{-1}\right)$ in 2007 to $0.45 \mathrm{l} \mathrm{kg}^{-1}$ (3.0 $\left.\mathrm{gal} \mathrm{bu}^{-1}\right)$ in 2016 (English et al. 2006).

Tillage Adoption Scenarios. Two conservation tillage adoption scenarios were simulated for the 2007 through 2016 period. The base scenario assumes that the proportion of land area in each tillage practice for each crop was held constant at 2007 levels estimated from CTIC data (CTIC 2007). Thus, the "total" tillage practice proportions

\section{Table 1}

USDA baseline year 2007 US crop area and US net farm income (NFI), and projected year 2016 US crop area and US NFI for alternative corn starch ethanol production scenarios.

\begin{tabular}{|c|c|c|c|c|c|c|}
\hline \multirow[b]{3}{*}{ Crop } & \multirow[b]{3}{*}{$2007 \S$} & \multicolumn{5}{|c|}{ Ethanol production (million $\mathrm{kL} \mathrm{y}^{-1}$ in 2016)* } \\
\hline & & \multicolumn{4}{|c|}{ Without CRP land† } & \multirow{2}{*}{$\begin{array}{l}\text { With CRP land¥ } \\
67.9\end{array}$} \\
\hline & & 32.5 & 45.3 & 60.4 & 67.9 & \\
\hline \multicolumn{7}{|c|}{ Crop area (million ha) } \\
\hline Barley & 1.417 & 1.385 & 1.417 & 1.389 & 1.453 & 1.976 \\
\hline Corn & 34.818 & 33.138 & 36.437 & 39.490 & 40.466 & 42.692 \\
\hline Cotton & 5.547 & 5.603 & 5.587 & 4.874 & 5.142 & 4.676 \\
\hline Hay & 25.142 & 25.283 & 25.182 & 24.484 & 24.267 & 24.587 \\
\hline Oats & 1.660 & 1.664 & 1.660 & 1.628 & 1.640 & 2.146 \\
\hline Rice & 1.255 & 1.259 & 1.251 & 1.194 & 1.186 & 1.287 \\
\hline Sorghum & 2.429 & 2.227 & 2.227 & 2.211 & 2.202 & 2.336 \\
\hline Soybeans & 28.745 & 30.794 & 27.854 & 26.502 & 26.692 & 26.372 \\
\hline Wheat & 24.291 & 23.781 & 23.684 & 23.324 & 22.061 & 22.915 \\
\hline \multicolumn{7}{|c|}{ NFI (billion US dollars) } \\
\hline & 61.300 & 56.084 & 62.800 & 67.284 & 70.897 & 65.880 \\
\hline
\end{tabular}

Note: $\mathrm{CRP}=$ Conservation Reserve Program.

* 2007 USDA agricultural baseline (USDA ERS 2007) forecast that ethanol output will rise from 32.5 million $\mathrm{kL} \mathrm{y}^{-1}$ in year 2007 to 45.3 million $\mathrm{kL} \mathrm{y}^{-1}$ in year 2016. The alternative ethanol production scenarios for 2016 are 32.5 (no growth over the 2007 level in the 2007 USDA agricultural baseline) 60.4, and 67.9 million $\mathrm{kL} \mathrm{y}^{-1}$ in year 2016.

† Assumes land area in the Conservation Reserve Program (CRP) for the 2007 through 2016 period in the 2007 USDA agricultural baseline (USDA ERS 2007). The baseline assumes that land area enrolled in the CRP decline with high crop prices early on and then gradually rise to its legislated maximum of 15.9 million ha by 2016 in response to higher CRP rental rates. $\ddagger$ Assumes land area in the CRP can come into crop production above levels projected in the 2007 USDA agricultural baseline (USDA ERS 2007).

$\S \mathrm{NFI}$ and crop area in year 2007 of the 2007 to 2016 USDA agricultural baseline (USDA ERS 2007).

of all croplands were allowed to vary as land changes from one crop to another under the static tillage adoption scenario. The second alternative had conservation tillage adoption follow historical trend patterns for each crop for 2007 through 2016. The static tillage adoption scenario was compared to the trend tillage adoption alternative to evaluate the potential impacts of additional conservation tillage adoption on mitigating soil erosion and $\mathrm{C}$ emissions from agricultural lands. Tillage adoption linear trends were calculated for each CRD. If the trend line rate of no-tillage adoption reached $100 \%$ in a CRD, then the no-tillage practice proportion was set to $100 \%$ for that year and any following years in the simulation. Conservation Reserve Program land was assumed to come into crop production using the same proportions of each tillage practice for each crop as other cropland in a CRD.

\section{Results and Discussion}

Results and discussion focus on comparisons for year 2016 of the simulation of the 67.9 million $\mathrm{kL} \mathrm{y}^{-1}$ (18 billion gal $\mathrm{yr}^{-1}$ ) ethanol scenario with the 45.3 million $\mathrm{kL} \mathrm{y}^{-1}$ (12 bil-

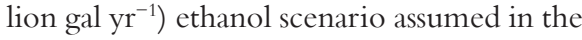
baseline (USDA ERS 2007). The NFI, land use, and environmental indicator results for the 32.5 million $\mathrm{kL} \mathrm{y}^{-1}$ (8.6 billion gal $\mathrm{yr}^{-1}$ ) and $60.4 \mathrm{M} \mathrm{kL} \mathrm{yr}^{-1}$ (16 billion gal) ethanol scenarios are provided in tabular form (tables 1, 2, and 3).

Impacts on Net Farm Income. United States agricultural sector NFI for the baseline (USDA ERS 2007) was \$62.8 B in year 2016 (table 1). Without CRP land coming into crop production, NFI for the 67.9 million $\mathrm{kL} \mathrm{y}^{-1}$ (18 billion gal $\mathrm{yr}^{-1}$ ) ethanol scenario was $12.9 \%(\$ 8.1 \mathrm{~B})$ larger than the baseline in year 2016 of the simulation (table $1)$. With the rise in NFI, government payments to farmers decreased by $2.4 \%$ relative to the baseline in year 2016. The estimated changes in government payments did not include potential payments to those who blend ethanol with gasoline. Results indicate that increasing corn ethanol production in the United States is projected to have a 
substantial positive economic impact on the US farm sector through enhanced NFI and lower government payments to farmers.

When CRP land was allowed to come into crop production above baseline levels, NFI increased by only $4.9 \%$ ( $\$ 3.1 \mathrm{~B}$ ) over the baseline in year 2016 (table 1). Total land area in all crops in the United States in year 2016 was 3.5\% (3.55 million ha [8.78 million ac]) larger when CRP land was allowed to be converted to crop production to meet higher demand for ethanol from corn starch (table 2). In the simulation, prices of crops declined relative to the non-CRP scenario as more land was planted in crops and output was expanded. The projected reduction in government payments to farmers relative to the baseline of $1.5 \%$ was also smaller than the reduction for the non-CRP scenario. Results indicate that if CRP land is converted to crop production in response to higher demand for ethanol, individual farmers will plant more land in crops, including corn. With a larger total US land area in crops due to individual farmer cropping choices, total US crop output will rise which will decrease crop prices and aggregate NFI relative to the nonCRP land scenario, if all other factors remain the same.

Impacts on Land Use. To accommodate the rise in ethanol production under the baseline (USDA ERS 2007), 36.4 million ha (90 million ac) of corn were forecast in the United States by year 2016, an increase of 4.7\% (1.6 million ha [4.0 million ac]) over area of 34.8 million ha (86 million ac) in year 2007 (table 1). Assuming that CRP land was not available for crop production above baseline levels, increasing ethanol output to 67.9 million $\mathrm{kL} \mathrm{y}^{-1}$ (18 billion gal $\left.\mathrm{yr}^{-1}\right)$ in year 2016 boosted corn area by $11.1 \%$ over the baseline in year 2016 to 40.5 million ha $(100$ million ac). The rise in corn area of 4.0 million ha (10 million ac) was coupled with respective declines from baseline levels in cotton, hay, rice, soybean, and wheat area of $0.45,0.91,0.06,1.16$, and 1.62 million ha $(1.1,2.3,0.2,2,9$, and 4.0 million ac). The impacts on crop area were even larger when CRP land was allowed to go into crop production above baseline levels (table 1). Corn area in year 2016 of the simulation was $17.2 \%$ (6.3 million ha [15.5 million ac]) more than under the baseline.

Corn area expanded throughout the United States in year 2016 of the simulation in response to higher demand for corn starch ethanol. Without CRP land, the

Table 2

Projected crop area by tillage practice for alternative corn starch ethanol production scenarios.

\begin{tabular}{|c|c|c|c|c|}
\hline \multirow{3}{*}{$\begin{array}{l}\text { Tillage adoption } \\
\text { scenario/tillage practice }\end{array}$} & \multirow[b]{3}{*}{$2007 \S$} & \multicolumn{3}{|c|}{ Ethanol production (million kL $\mathrm{y}^{-1}$ in 2016)* } \\
\hline & & \multicolumn{2}{|c|}{ Without CRP land $†$} & \multirow{2}{*}{$\frac{\text { With CRP land }}{67.9}$} \\
\hline & & 45.3 & 67.9 & \\
\hline \multicolumn{5}{|l|}{ Crop area (million ha) } \\
\hline \multicolumn{5}{|l|}{ Static adoption $\|$} \\
\hline Conventional tillage & 36.16 & 36.15 & 36.92 & 38.43 \\
\hline Reduced tillage & 39.99 & 39.98 & 40.09 & 41.59 \\
\hline No-tillage & 24.01 & 24.00 & 23.84 & 24.37 \\
\hline Total & 100.16 & 100.12 & 100.84 & 104.40 \\
\hline \multicolumn{5}{|l|}{ Trend adoption $\|$} \\
\hline Conventional tillage & 36.16 & 32.66 & 33.12 & 34.60 \\
\hline Reduced tillage & 39.99 & 35.29 & 35.85 & 37.11 \\
\hline No-tillage & 24.01 & 32.16 & 31.88 & 32.68 \\
\hline Total & 100.16 & 100.12 & 100.84 & 104.40 \\
\hline
\end{tabular}

Note: CRP = Conservation Reserve Program.

* 2007 USDA agricultural baseline (USDA ERS 2007) forecast that ethanol output will rise from 32.5 million kL $\mathrm{y}^{-1}$ in 2007 to 45.3 million $\mathrm{KL} \mathrm{y}^{-1}$ in 2016 . The alternative ethanol production scenarios for 2016 are 32.5 (no growth over the 2007 level in the 2007 USDA agricultural baseline) 60.4, and 67.9 million $\mathrm{kL} \mathrm{y}^{-1}$ in 2016.

† Assumes land area in the Conservation Reserve Program (CRP) for the 2007 through 2016 period in the 2007 USDA agricultural baseline (USDA ERS 2007). The baseline assumes that land area enrolled in the CRP decline with high crop prices early in period and then gradually rise to its legislated maximum of 15.9 million ha by 2016 in response to higher CRP rental rates.

$\ddagger$ Assumes land area in the CRP can come into crop production above levels projected in 2007 USDA agricultural baseline (USDA ERS 2007).

$\S$ Crop area in year 2007 of the 2007 USDA agricultural baseline (USDA ERS 2007).

|| The two tillage-adoption scenarios modeled for each CRD were (1) conventional, reduced, and no-tillage land proportions among crops were assumed to not change from year 2007 levels for the 2007 through 2016 simulation (static adoption) and (2) conservation tillage adoption followed historical trend adoption patterns for each crop for the 2007 through 2016 simulation (trend adoption).

largest forecasted gains in corn area were concentrated in western Nebraska, western Kansas, the panhandle of north Texas, and parts of southern Michigan, as well as a large area in the traditional corn-producing area of southern Minnesota, Iowa, and Illinois in the Heartland (figure 2). With CRP land, the largest forecasted gains in corn area encompassed a bigger proportion of the Heartland and larger areas in adjacent Farm Resource Regions (figure 2). Thus, the largest increases in corn production covered a larger proportion of the Prairie Gateway, with the largest estimated gains in area in eastern Colorado, Nebraska, Kansas, eastern New Mexico, and the panhandle of north Texas. Corn production also rose in the northern Great Plains and the Fruitful Rim, with the largest estimated gains in northwestern Minnesota, the eastern Dakotas, western Washington, and eastern Idaho. Finally, corn production expanded in the Mississippi Portal, with the largest projected increase in west Tennessee.
While not shown graphically, cotton production in relative terms shifted westward out of the Southern Seaboard and Mississippi Portal into the irrigated production areas of the Prairie Gateway and Fruitful Rim. Wheat production migrated south and east into the Prairie Gateway, Eastern Uplands, Mississippi Portal, and Southern Seaboard. Soybeans production moved from the Heartland to adjacent areas of the Northern Great Plains, Prairie Gateway, and Mississippi Portal.

Impacts on Tillage. Historically, the proportion of corn produced in the United States using conventional tillage has been higher than for soybeans (CTIC 2007). Current tillage data indicate that $38 \%$ of corn area is grown using conventional tillage, while only $20 \%$ of soybean area is produced using conventional tillage (CTIC 2007). Thus, the potential exists for more crop area to be tilled as more corn is grown to support higher ethanol demand. The base conservation tillage adoption scenario assumed that the tillage 


\section{Figure 2}

Projected changes in corn area by crop reporting district on (a) non-Conservation Reserve Program land and (b) Conservation Reserve Program land in 2016 by increasing US corn starch ethanol production from 45.3 to 67.9 million $\mathrm{KL} \mathrm{y}^{-1}$.
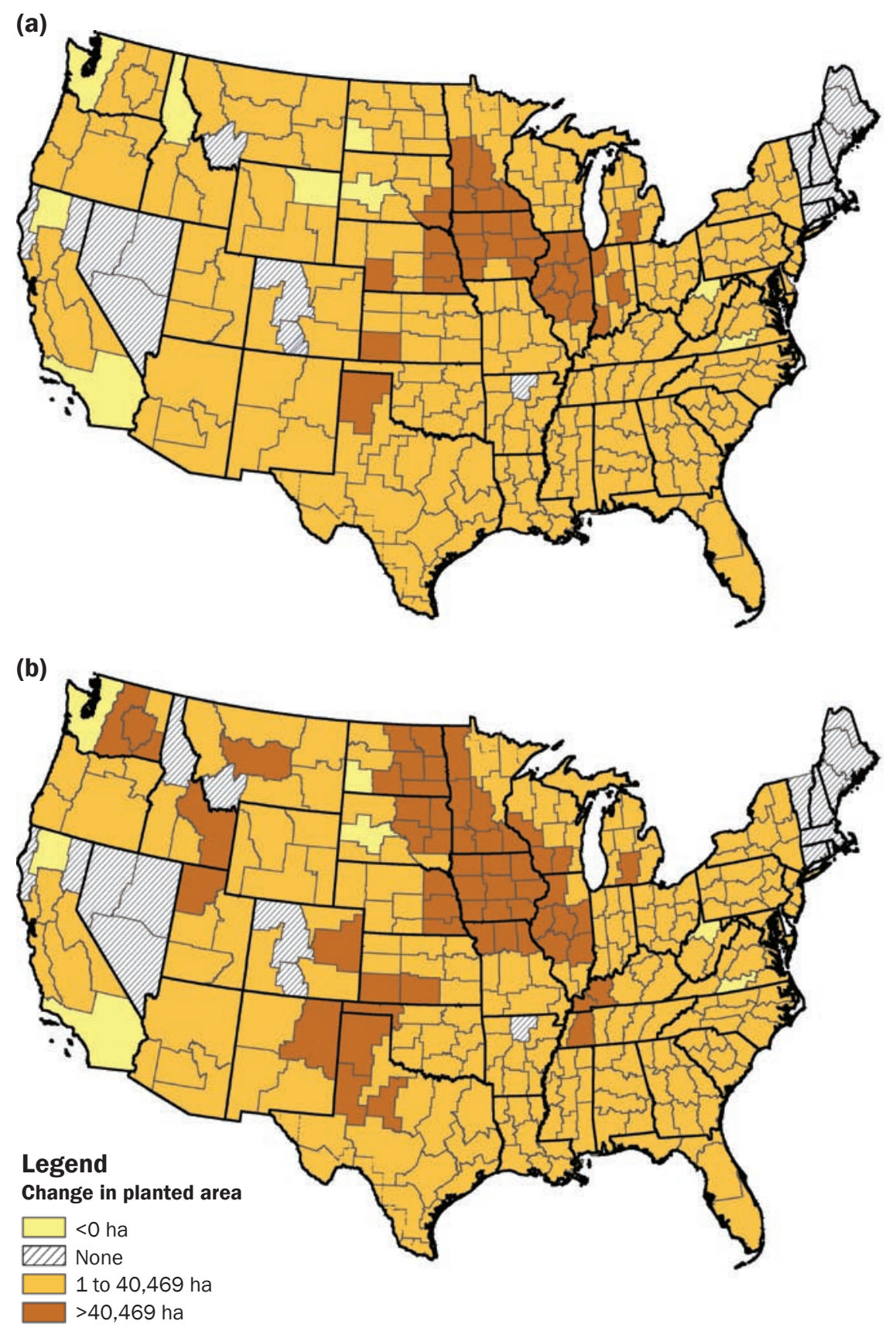

proportions for each crop remained at year 2007 levels for the 10-year period. Thus, for the baseline, the percentages of the total crop area of 100.12 million ha (247.3 million ac) for the baseline in year 2016 that were produced using no-tillage and conventional tillage were estimated to be $24 \%$ and $36.1 \%$, respectively (table 2). As ethanol output was increased above the baseline to 67.9 million

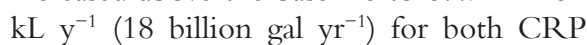
scenarios, more land that was produced with crops having a higher no-tillage proportion was switched to corn, which had a higher conventional tillage proportion (table 2). Results indicate that if adoption of conservation tillage does not rise with increased corn production for ethanol, a larger proportion of total US crop area will be tilled using conventional methods.

Further adoption of no-tillage in corn production has the potential to mitigate the potential negative effects of increased corn production on total crop area in conservation tillage in the United States. Under the baseline ethanol output scenario for year 2016, the percentage of total US crop area in no-tillage increased from $24 \%$ under the static conservation tillage adoption assumption to $32.1 \%$ under the trend conservation tillage assumption (table 2). By comparison, the total amount of cropland in conventional tillage dropped from $36.1 \%$, assuming static conservation tillage adoption, to $32.6 \%$, assuming trend conservation tillage adoption (table 2). Similar proportions of land in conventional and no-tillage for year 2016 were estimated for the trend tillage adoption assumption for the 67.9 million $\mathrm{kL} \mathrm{y}^{-1}$ (18 billion gal $\mathrm{yr}^{-1}$ ) ethanol scenario with and without CRP land (table 2).

Impacts on the Environment. The forecast trend over the 2007 to 2016 period was for a rise in total fertilizer and $\mathrm{N}$ fertilizer expenditures as corn area was expanded to meet increased demand for ethanol. In year 2016 of the simulation, annual fertilizer expenditures were 3.7\% ( $\$ 289$ million) larger relative to the baseline (table 3 ). The estimated difference in annual fertilizer expenditures in year 2016 was even more magnified when CRP land was assumed available for crop production, increasing by $11.5 \%$ ( $\$ 887$ million) above the baseline (table 3). Regional changes in $\mathrm{N}$ fertilizer expenditures mirrored changes in cropping patterns due to increased corn production (figure 3). As with planted corn area, much of the United States has larger $\mathrm{N}$ fertilizer expenditures due to more corn area being planted. The largest increases in $\mathrm{N}$ fertilizer expenditures occurred in the traditional corn-producing area of the Heartland and adjacent regions. On the other hand, $\mathrm{N}$ fertilizer use declined in some sections of the lower Mississippi River Basin in the Mississippi Portal as cotton area is reduced and more soybeans are grown. In addition, total fertilizer expenditures fell in the northern Great Plains as soybeans replaced wheat.

Nonfertilizer chemical usage in year 2016 of the simulation increased by $5.9 \%$ ( $\$ 544$ million) and 6.7\% (\$616 million), respectively, under the non-CRP and CRP scenarios 


\section{Table 3}

Projected US agricultural sector environmental indicators in 2016 for alternative corn starch ethanol production scenarios.

\begin{tabular}{|c|c|c|c|c|c|c|}
\hline \multirow[b]{3}{*}{ Indicator } & \multirow[b]{3}{*}{$2007 \S$} & \multicolumn{5}{|c|}{ Ethanol production (million $\mathrm{kL} \mathrm{y}^{-1}$ in 2016)* } \\
\hline & & \multicolumn{4}{|c|}{ Without CRP land† } & \multirow{2}{*}{$\frac{\text { With CRP land } \neq}{67.9}$} \\
\hline & & 32.5 & 45.3 & 60.4 & 67.9 & \\
\hline \multicolumn{7}{|c|}{ Input expenditures (US billion dollars) $\|$} \\
\hline All fertilizer & 7.603 & 7.379 & 7.713 & 7.892 & 8.001 & 8.600 \\
\hline $\mathrm{N}$ fertilizer & 4.527 & 4.368 & 4.633 & 4.799 & 4.871 & 5.089 \\
\hline Chemicals & 9.348 & 9.173 & 9.446 & 9.497 & 9.717 & 9.789 \\
\hline \multicolumn{7}{|l|}{ Soil and air (million Mg) } \\
\hline \multicolumn{7}{|l|}{ Soil erosion\# } \\
\hline Static adoption** & 718.250 & 712.131 & 722.037 & 731.745 & 735.518 & 736.042 \\
\hline Trend adoption** & 718.250 & 659.120 & 668.621 & 677.495 & 680.703 & 706.439 \\
\hline \multicolumn{7}{|l|}{ C emissions†† } \\
\hline Static adoption** & 35.149 & 34.602 & 35.387 & 35.657 & 35.794 & 37.007 \\
\hline Trend adoption** & 35.149 & 30.129 & 31.425 & 31.672 & 32.643 & 33.774 \\
\hline \multicolumn{7}{|l|}{ soct† } \\
\hline Static adoption** & 9.660 & 9.803 & 9.601 & 9.535 & 9.542 & 9.814 \\
\hline Trend adoption** & 9.660 & 12.084 & 11.888 & 11.884 & 11.902 & 12.244 \\
\hline
\end{tabular}

Note: $\mathrm{CRP}=$ Conservation Reserve Program. $\mathrm{N}=$ nitrogen. $\mathrm{C}=$ carbon. $\mathrm{SOC}=$ soil organic carbon.

* 2007 USDA agricultural baseline (USDA ERS 2007) forecast that ethanol output will rise from 32.5 million kL $y^{-1}$ in 2007 to 45.3 million kL $y^{-1}$ in 2016. The alternative ethanol production scenarios for 2016 are 32.5 (no growth over the 2007 level in the 2007 USDA agricultural baseline) 60.4 , and 67.9 million $\mathrm{kL} \mathrm{y}^{-1}$ in 2016.

† Assumes land area in the Conservation Reserve Program (CRP) for the 2007 through 2016 period in the 2007 USDA agricultural baseline (USDA ERS, 2007). The baseline assumes that land area enrolled in the CRP decline with high crop prices early in period and then gradually rise to its legislated maximum of 15.9 million ha by 2016 in response to higher CRP rental rates.

‡ Assumes land area in the CRP can come into crop production above levels projected in 2007 USDA agricultural baseline (USDA ERS 2007).

$\S$ Indicators calculated using crop areas in year 2007 of the 2007 USDA agricultural baseline (USDA ERS 2007).

|| Expenditures were calculated using prices in the 2007 USDA agricultural baseline (USDA ERS 2007) for all ethanol scenarios.

\# Estimated water induced soil erosion (sheet and rill) based on projected changes in crop area for barley, corn, cotton, oats, rice, sorghum, soybean, and wheat. The erosion estimates do not include area for pasture, hay, and other crops not in POLYSYS.

** The two tillage adoption scenarios modeled for each CRD were (1) conventional, reduced, and no-tillage land proportions among crops were assumed to not change from year 2007 levels for the 2007 through 2016 simulation (static adoption) and (2) conservation tillage adoption followed historical trend line adoption patterns for each crop for the 2007 through 2016 simulation (trend adoption).

$\dagger \dagger$ Incorporated changes in C emissions and soil organic C (SOC) sequestration from changes in land use (table 1).

(table 3). While not shown graphically, not all regions had increased chemical expenditures in the simulation. For example, 90 of the 305 CRDs either had no change or had a decrease in chemical expenditures under the non-CRP scenario. Many of the CRDs that had projected reductions in expenditure were concentrated in the Fruitful Rim, Prairie Gateway, Mississippi Portal, and Southern Seaboard, where less cotton was grown in year 2016. Nonfertilizer chemical expenditures for cotton on a land-area basis were greater than for the crops that replaced cotton in these regions.

Total annual soil erosion by water (sheet and rill) in year 2007 for the United States, as predicted by POLYSYS under the baseline, was 718 million $\mathrm{Mg} \mathrm{y}^{-1}$ (792 million tn $\mathrm{yr}^{-1}$ ) (table 3). The estimate of soil erosion com-

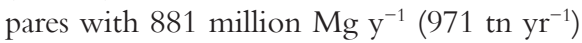

of erosion in 2003, estimated by the USDA NRCS (USDA NRCS 2007a). The erosion estimates from POLYSYS do not include hayland, pastureland, and other crops not in POLYSYS and thus may explain the difference between the two estimates. In addition, differences in tillage practices and crop mix for the two different years may also be a factor in explaining the difference between the two estimates.

Assuming static conservation tillage adoption, annual soil erosion in year 2016 under the baseline ethanol scenario rose by less than $1 \%$ to 722.0 million $\mathrm{Mg} \mathrm{y}^{-1}$ (796.1 million $\mathrm{tn}^{\mathrm{yr}^{-1}}$ ) from the level estimated for year 2007 (table 3). Without CRP land coming into production above baseline levels, increasing ethanol output to 67.9 million $\mathrm{kL}$ $\mathrm{y}^{-1}$ (18 billion gal $\left.\mathrm{yr}^{-1}\right)$ boosted annual soil erosion by $1.8 \%$ (13.5 million $\mathrm{Mg} \mathrm{y}^{-1}$ [14.9

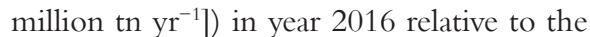
baseline (table 3). With CRP land, estimated annual erosion in year 2016 relative to the baseline was slightly larger than the nonCRP scenario (table 3). Results also indicate that continued adoption of conservation tillage has the potential to mitigate the effects of expanded ethanol production of 67.9 million $\mathrm{kL} \mathrm{y}^{-1}$ on aggregate soil erosion in the United States. The model predicted that annual soil erosion in year 2016 for the nonCRP and CRP scenarios were 7.5\% (54.8 million $\mathrm{Mg} \mathrm{y}^{-1}$ [60.4 million tn $\mathrm{yr}^{-1}$ ]) and 4.0\% less (29.6 million $\mathrm{Mg} \mathrm{y}^{-1}$ [32.6 million tn $\left.\left.\mathrm{yr}^{-1}\right]\right)$, respectively, for the trend tillage adoption scenario when compared with the static tillage adoption scenario.

Notwithstanding the projected reductions in aggregate annual soil erosion for the United States with increased conservation 


\section{Figure 3}

Projected changes in annual $\mathrm{N}$ fertilizer use by crop reporting district on (a) non-Conservation Reserve Program land and (b) Conservation Reserve Program land in 2016 by increasing US corn starch ethanol production from 45.3 to 67.9 million $\mathrm{kL} \mathrm{y}^{-1}$.

(a)

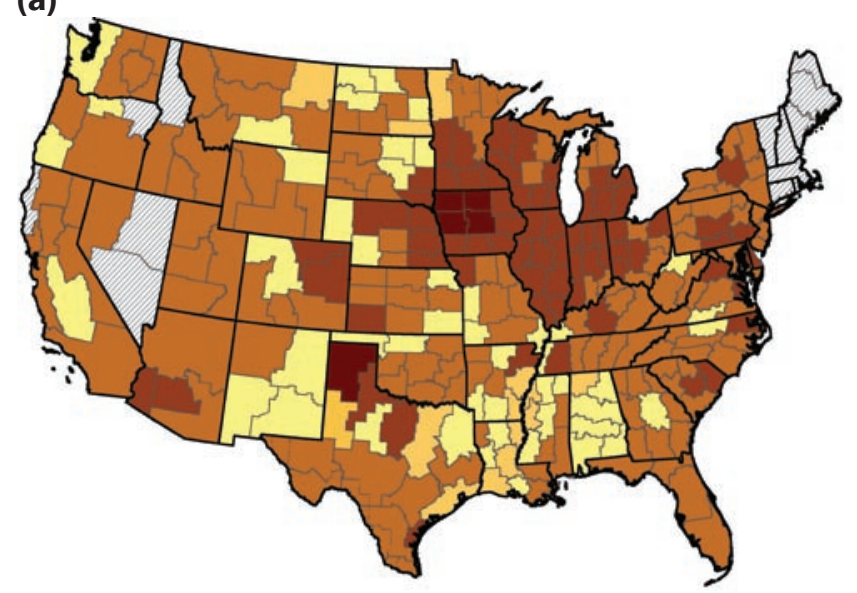

(b)

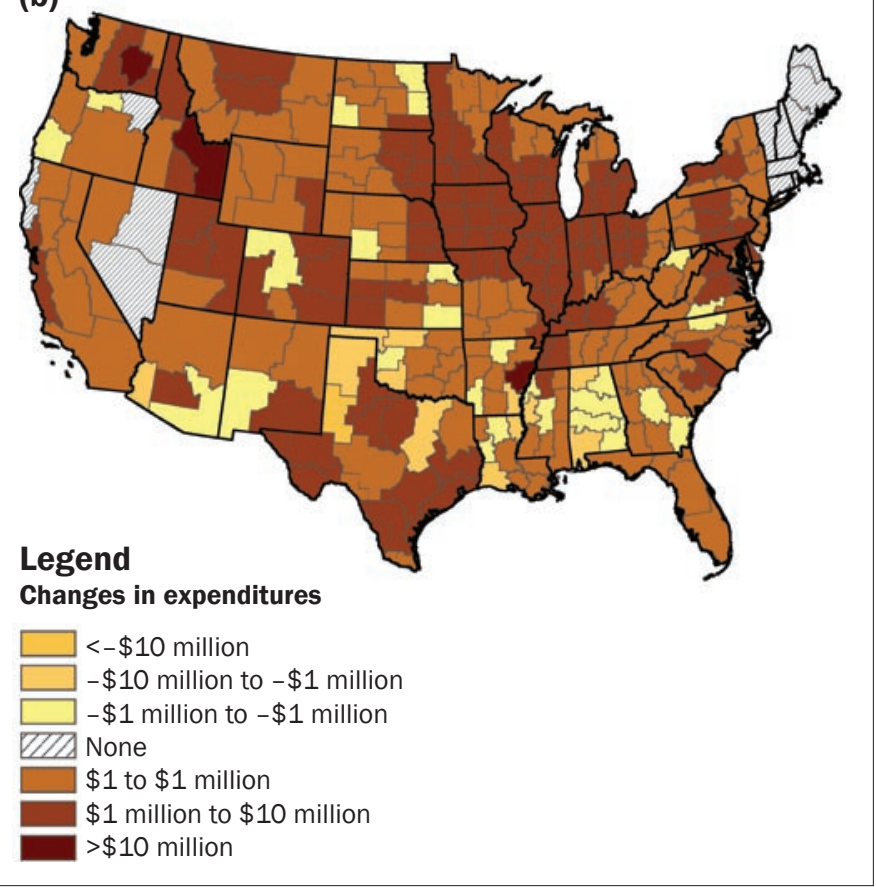

\section{Figure 4}

Projected changes in annual soil erosion by crop reporting district relative to (a) static conservation tillage adoption and (b) trend conservation tillage adoption in 2016 by increasing US corn starch ethanol production from 45.3 to 67.9 million $\mathrm{KL}^{-1}$, assuming Conservation Reserve Program lands were available for crop production.

(a)

(b)
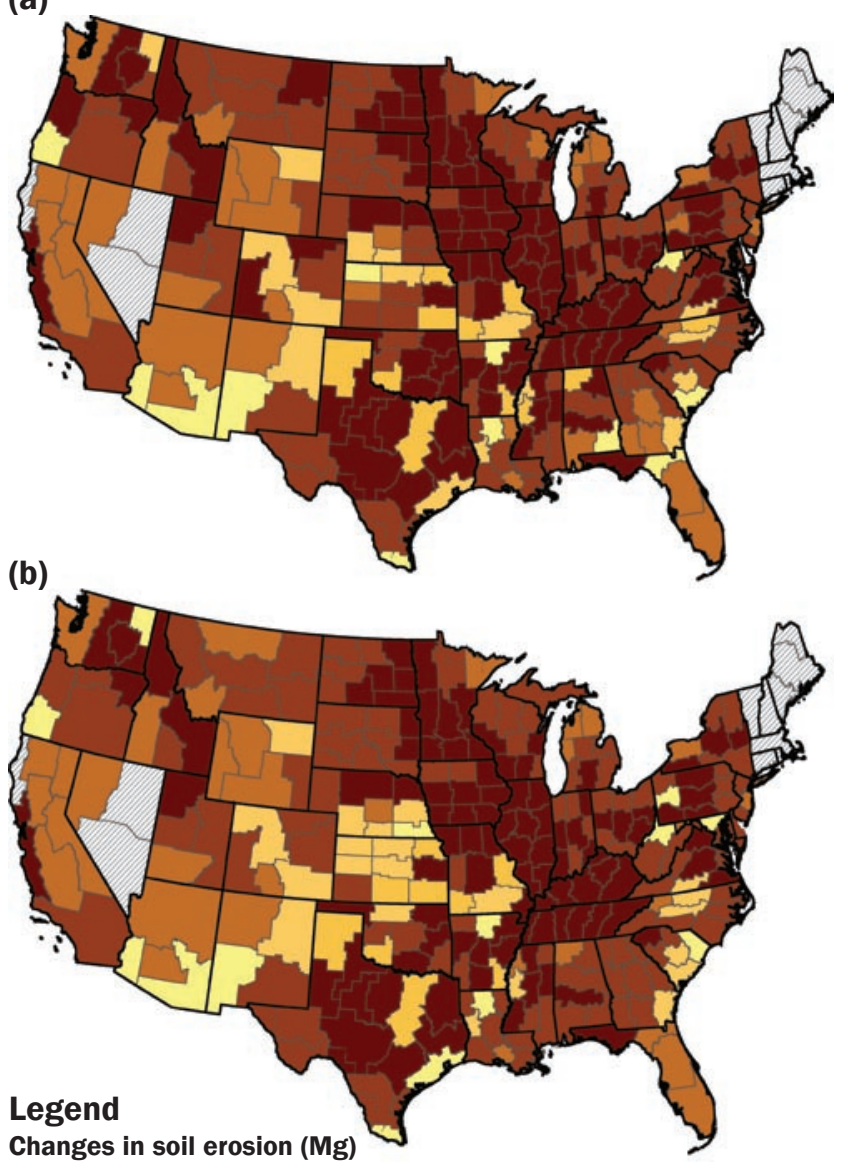

Changes in soil erosion (Mg)

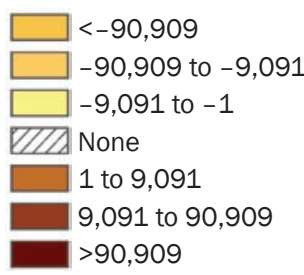

tillage adoption, substantial erosion was still predicted for areas of the United States for the increased ethanol production using the CRP land scenario (figure 4). For both tillage adoption scenarios, nearly all of the CRDs in Iowa, Illinois, Kentucky, and Tennessee had increased erosion levels of $90,718 \mathrm{Mg}$ $\mathrm{y}^{-1}\left(100,000\right.$ tn $\left.\mathrm{yr}^{-1}\right)$ or more over levels in the baseline by year 2016 of the simulation. In addition, about half of the CRDs in Arkansas, Idaho, Indiana, Minnesota, Missouri, Mississippi, North Dakota, Ohio, Pennsylvania, and Texas had increased ero- sion levels of $90,718 \mathrm{Mg} \mathrm{y}^{-1}(100,000 \mathrm{tn}$ $\mathrm{yr}^{-1}$ ) or more over levels in the baseline in year 2016. Results indicate that policies and programs to limit soil erosion's impact from increased corn production for ethanol should be focused on these growing areas to maximize potential benefits.

Assuming static conservation tillage adoption, simulation results indicate that annual C emissions from crop activities increased as corn production rose in response to higher corn starch ethanol demand (table 3). Carbon emissions on an annualized basis for the baseline increased by less than $1 \%$, rising from 35.1 million $\mathrm{Mg} \mathrm{C} \mathrm{y}{ }^{-1}$ (38.8 million

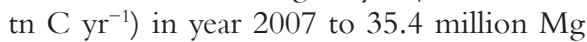
$\mathrm{C} \mathrm{y}^{-1}$ (39.0 million tn $\left.\mathrm{C} \mathrm{yr}^{-1}\right)$ in year 2016 (table 3). Annual $\mathrm{C}$ emissions were higher relative to the baseline for the 67.9 million $\mathrm{kL} \mathrm{y}^{-1}$ (18 billion gal $\mathrm{yr}^{-1}$ ) ethanol scenario and were $1.2 \%$ (0.41 million $\mathrm{Mg} \mathrm{C} \mathrm{y}^{-1}[0.45$ million th $\left.\left.\mathrm{yr}^{-1}\right]\right)$ and $4.6 \%$ (1.62 million $\mathrm{Mg} \mathrm{C} \mathrm{yr}{ }^{-1}$ [1.79 million tn $\left.\left.\mathrm{C} \mathrm{yr}^{-1}\right]\right)$ larger, respectively, for the non-CRP and CRP land options in year 2016. When conservation tillage adoption was assumed to increase 


\section{Figure 5}

Projected changes in annual carbon emissions by crop reporting district relative to (a) static conservation tillage adoption and (b) trend conservation tillage adoption in 2016 by increasing US corn starch ethanol production from 45.3 to 67.9 million $\mathrm{kL} \mathrm{y}^{-1}$, assuming Conservation Reserve Program lands were available for crop production.

(a)
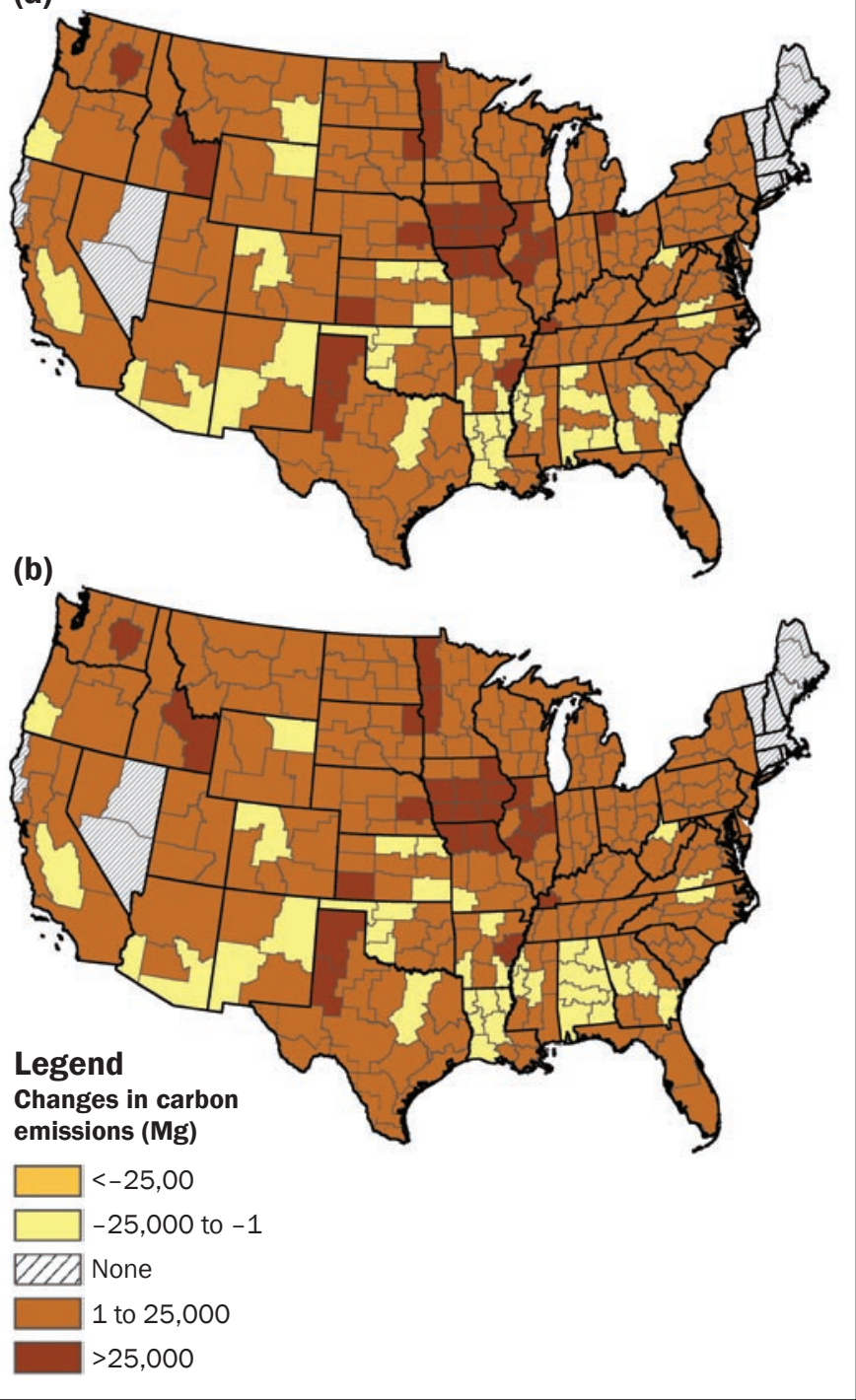

Figure 6

Projected changes in annual soil carbon sequestration by crop reporting district relative to (a) static conservation tillage adoption and (b) trend conservation tillage adoption in 2016 by increasing US corn starch ethanol production from 45.3 to 67.9 million kL y'${ }^{-1}$, assuming Conservation Reserve Program lands were available for crop production.

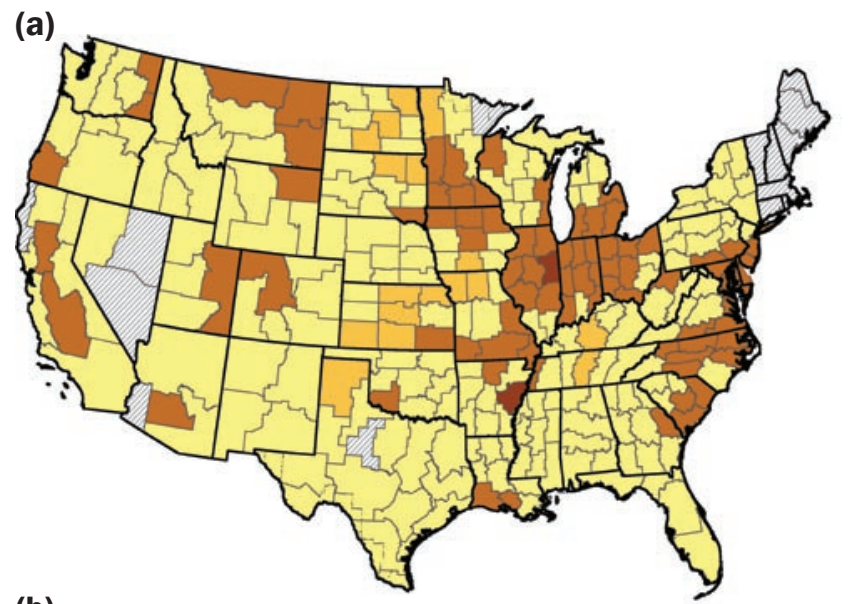

(b)

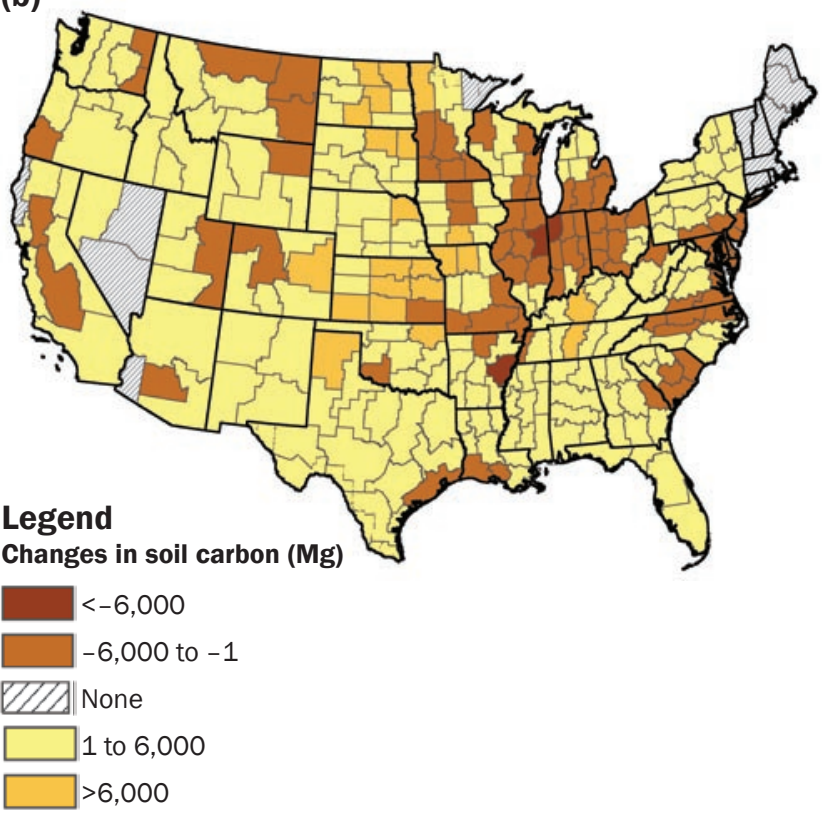

at historical trend rates for each crop in the 10-year period, annual $\mathrm{C}$ emissions for the baseline in year 2016 dropped by $10.6 \%$ to 31.43 million $\mathrm{Mg} \mathrm{C} \mathrm{y}^{-1}$ (34.65 million tn $\mathrm{C}$ $\mathrm{yr}^{-1}$ ) (table 3). Results indicate that annual $\mathrm{C}$ emissions from increased corn production could be mitigated through additional conversion of land to no-tillage. The model predicted that annual $\mathrm{C}$ emissions in year 2016 for the non-CRP and CRP options for the 67.9 million $\mathrm{kL} \mathrm{y}^{-1}$ ethanol scenario were reduced from year 2007 levels by $7.1 \%$ (2.51

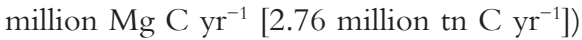

and 3.9\% (1.38 million $\mathrm{Mg} \mathrm{C}^{-1}$ [1.52 million tn $\left.\mathrm{C} \mathrm{yr}^{-1}\right]$ ), respectively (table 3 ).

Regional increases in annual $\mathrm{C}$ emissions relative to the baseline for the 67.9 million

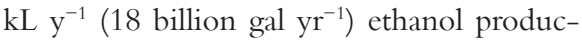
tion with CRP land scenario for year 2016 followed changes in cropping patterns and input usage due to increased corn production (figure 5). Higher fertilizer and other input usage and increased tillage intensity for corn production relative to most other crops impacted the regional differences in annual $\mathrm{C}$ emissions. Regional differences in the conversion of CRP land into crop production also influenced regional differences in annual $\mathrm{C}$ emissions in the simulation.

Assuming static conservation tillage adoption, annual SOC sequestered in agricultural soils in year 2016 for the baseline was estimated to be 9.60 million $\mathrm{Mg} \mathrm{C} \mathrm{y}{ }^{-1}$ (10.59 million tn $\mathrm{C} \mathrm{yr}^{-1}$ ) for all of the United States (table 3). Soil organic carbon results for the 67.9 million $\mathrm{kL} \mathrm{y}^{-1}$ (18 billion gal $\mathrm{yr}^{-1}$ ) ethanol production scenario indicate that annual SOC accumulations declined slightly from the levels estimated for the baseline (table 3). 
When conservation tillage adoption was assumed to increase at historical trend rates for each crop in the simulation, the estimated annual amount of SOC sequestered in year year 2016 for the baseline was $23.8 \%$ greater (2.29 million $\mathrm{Mg} \mathrm{C} \mathrm{y}^{-1}$ [2.52 million th $\left.\mathrm{C} \mathrm{yr}^{-1}\right]$ ) than under the static conservation tillage adoption assumption (table 3). In contrast to the static tillage adoption alternative, annual SOC sequestered in year 2016 of the simulation for the 67.9 million $\mathrm{kL} \mathrm{y}^{-1}$ (18 billion gal $\mathrm{yr}^{-1}$ ) ethanol production scenario for both CRP land options rose slightly as more corn was planted using no-tillage. As with the other environmental indicators, the impacts of increased corn production on annual SOC accumulations varied regionally (figure 6). For the trend conservation tillage adoption scenario, losses of SOC still occurred in a large area of the Heartland and in selected areas of other regions.

Results from the simulation indicate that additional adoption of conservation tillage above year 2007 levels has the potential to mitigate the adverse effects of increased corn production on carbon emissions to the atmosphere. For example, annual net $\mathrm{C}$ emissions to the atmosphere (C emissions less SOC sequestered) for the baseline in year 2016 were reduced by 23.3\% (5.95 million $\mathrm{Mg} \mathrm{C} \mathrm{y}{ }^{-1}$ [6.56 million tn $\left.\mathrm{C} \mathrm{yr}^{-1}\right]$ ) from year 2007 levels. Nevertheless, net $\mathrm{C}$ emissions to the atmosphere in year 2016 increase substantially relative to the baseline for the 67.9 million $\mathrm{kL} \mathrm{y}^{-1}$ (18 billion gal $\mathrm{yr}^{-1}$ ) ethanol scenario with trend tillage adoption. Net $\mathrm{C}$ emission to the atmosphere rose by $6.2 \%$ (1.20 million $\mathrm{Mg} \mathrm{C} \mathrm{y}{ }^{-1}[1.33$ million th $\mathrm{C} \mathrm{yr}^{-1}$ ]) relative to the baseline for the non-CRP scenario. By comparison, net $\mathrm{C}$ emissions to the atmosphere climbed by 10.2\% (1.99 million $\mathrm{Mg} \mathrm{C} \mathrm{y}^{-1}$ [2.20 million

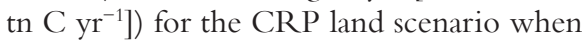
compared to the baseline.

\section{Summary and Conclusions}

This study used an economic and environmental simulation model to evaluate the impacts of increased ethanol production from corn starch on land use and the environment for the United States agricultural sector for 2007 through 2016. Simulation results indicate that land use shifted from other crops into corn to support increased ethanol production, and crop prices for those crops increased. Thus, expanded corn production had a substantial positive impact on realized NFI and economic wellbeing for the US agricultural sector. Government payments to farmers were reduced because of higher commodity prices and enhanced net farm income. If CRP land was converted to crop production in response to higher demand for ethanol, individual farmers would plant more land in crops, including corn. Thus, the larger total US land area in crops due to individual farmer cropping choices would cause total US crop output to rise, crop prices to fall, and aggregate net farm income to decline relative to the scenario where increased ethanol production occurred without CRP land. Corn production expanded throughout the United States, but the largest increases occurred in the traditional corn-producing region of the midcontinent United States and in adjacent regions. Cotton production in relative terms moved westward into irrigated production areas, and wheat production shifted into the southeast United States. Soybean production shifted from the midcontinent United States into adjacent regions.

The land-use changes had a substantial impact on the environment through changes in tillage intensity, fertilizer and chemical input usage, water-induced soil erosion and sedimentation, and $\mathrm{C}$ emissions/ $\mathrm{C}$ sequestration in agricultural soils. Fertilizer and chemical usage increased throughout the United States. Tillage intensity increased as more corn was planted in place of soybeans, which historically has had a greater proportion of its crop area grown under no-tillage than has corn. Thus, when conservation tillage adoption was assumed to remain at 2007 levels for the 10-year period, regional tillage intensity, soil erosion, and fossil fuelbased $\mathrm{C}$ emissions increased, whereas soil $\mathrm{C}$ stocks decreased as a result of increased corn production. Results from the simulation also indicate that additional adoption of conservation tillage above 2007 levels has the potential to mitigate the adverse effects of increased corn production on waterinduced soil erosion and net $\mathrm{C}$ emissions to the atmosphere.

Notwithstanding the potential of additional conservation tillage adoption to alleviate the effects of increased corn production on the environment for the United States as a whole, regional differences in environmental impacts indicate that some areas of the United States may benefit from poli- cies and programs to reduce soil erosion and net $\mathrm{C}$ emissions. In addition, fertilizer and chemical usage increased in many areas of the United States and may put water resources at greater risk for pollution. Higher crop prices with increased ethanol demand may provide farmers with an economic incentive to adopt precision farming practices to improve the efficiency of fertilizer and chemical usage in corn production. The potential availability of genetically modified crops with increased $\mathrm{N}$ efficiency may also mitigate some of the environmental impacts of increased corn production. Policies and incentives to encourage adoption of conservation tillage and precision farming practices should be targeted to high-risk areas identified in this analysis to maximize potential benefits.

\section{Acknowledgements}

This research was supported by a grant from the USDA Natural Resources Conservation Service entitled, "Economic and Environmental Impacts on Our Nation's Working Lands as a Result of Renewable Energy Production," and a grant from NASA Earth Science Division entitled, "Modeling and Mapping Land Management and Net Carbon Emissions: Decision Support for Biofuels and Carbon Management on U.S. Agricultural Lands."

\section{References}

AAEA (American Agricultural Economics Association). 1998. Commodity costs and returns estimation handbook. Ames, IA: American Agricultural Economics Association. http://www.economics.nrcs.usda.gov/ care/Aaea/index.html

Adler, P.R., S.J. Del Grosso, and W.J. Parton. 2007. Life-cycle assessment of net greenhouse-gas flux for bioenergy cropping systems. Ecological Applications 17:675-691.

Alexander, R.R., and B.C. English. 1988. Micro-Oriented Sediment Simulator Version 2.1 User's Manual. Research Report 88 - 21. Knoxville, TN: The University of Tennessee, Institute of Agriculture.

ASAE (American Society of Agricultural Engineers). 1999. ASAE standards: Standards, engineering practices and data adopted by the American Society of Agricultural Engineers. St. Joseph, MI: American Society of Agricultural Engineers.

Cassman, K.,V. Eidman, and E. Simpson. 2006. Convergence of agriculture and energy: Implications for research and policy. Council for Agricultural Science and Technology Commentary QTA 2006-3. Ames, IA: The Council for Agricultural Science and Technology. http://www.castscience.org.

CCSP (Climate Change Science Program). 2007. The First State of the Carbon Cycle Report (SOCCR): The North American Carbon Budget and Implications for 
the Global Carbon Cycle. A Report by the U.S. Climate Change Science Program and the Subcommittee on Global Change Research, ed. A.W. King, L. Dilling, G.P. Zimmerman,D.M.Fairman, R.A.Houghton, G.Marland, A.Z. Rose, and T.J. Wilbanks. Asheville, NC: National Oceanic and Atmospheric Administration, National Climatic Data Center. http://www.globalchange.gov/ publications/reports/scientific-assessments/saps/sap2-2.

CTIC (Conservation Technology Information Center). 2007. National crop residue management survey data. West Lafayette, IN: Conservation Technology Information Center. http://www.ctic.purdue.edu/CRM.

Daberkow, S., and W. Wang. 2006. Nutrient management. In Agricultural Resources and Environmental Indicators, 117-123. Economic Information Bulletin No. EIB-16. Washington DC: USDA Economic Research Service.

De La Torre Ugarte, D.G., D.E. Ray, and K.H. Tiller.1998. Using the POLYSYS modeling framework to evaluate environmental impacts on agriculture. In Evaluating Natural Resource Use in Agriculture, ed. T. Robertson, B.C. English and R.R. Alexander. Ames, IA: Iowa State University Press.

Donner, S.D., and C.J. Kucharik. 2008. Corn-based ethanol production compromises goal of reducing nitrogen export by the Mississippi river. Proceedings of the National Academy of Science 105:4513-4518.

English, B.C., D.G. De La Torre Ugarte, K. Jensen, C.M. Hellwinckel, J. Menard, B. Wilson, R. Roberts, and M. Walsh. 2006a. 25\% renewable energy for the United States by 2025: Agricultural and economic impacts. Knoxville, TN: Department of Agricultural Economics, University of Tennessee. http://www.agpolicy.org/ ppap/REPORT\%2025x25.pdf.

Lal, R. 2004. Carbon emissions from farm operations. Environment International 30:981-990.

Lal, R., J.M. Kimble, R.F. Follett, and C.V. Cole. 1998. The Potential of US Cropland to Sequester Carbon and Mitigate the Greenhouse Effect. Chelsea, MI: Sleeping Bear Press.

Marland, G., T.O. West, B. Schlamadinger, and L. Canella. 2003. Managing soil organic carbon in agriculture: The net effect on greenhouse gas emissions. Tellus B 55:613-622.

Miranowski, J., D. Swenson, L. Eathington, and A. Rosburg. 2008. Biofuel, the rural economy, and farm structure. In Risk, Infrastructure and Industry Evolution Proceedings of a conference, 23-28. June 24-25, 2008, in Berkeley, CA. Oak Brook, IL: Farm Foundation. http:// www.farmfoundation.org/news/articlefiles/365Berkeley\%20proceedings.pdf.

Nash, S. 2007. Decrypting biofuels scenarios. BioScience $57: 472-477$.
National Research Council. 1986. Soil conservation; assessing the national resources inventory. Washington DC: National Academy Press.

Nelson, R., C.M. Hellwinckel, C.C. Brandt, T.O. West, D.G. De La Torre Ugarte, and G. Marland. 2009. Energy use and carbon dioxide emissions from cropland production in the United States, 1990-2004. Journal of Environmental Quality 38:418-425.

Novack, N., and J. Henderson. 2007. Can ethanol power the rural economy? Main Street Economist 2(1).

Ogle, S.M., FJ. Breidt, M. Easter, S. Williams, K. Killian, and K. Paustain. 2009. Scale and uncertainty in modeling soil organic carbon stock changes for US croplands using a process-based model. Global Change Biology 15, doi:10.1111/j.1365-2486.2009.01951.x.

Renard, K.G., G.R. Foster, G.A.Weesies, D.K. McCool, and D.C.Yoder. 1997. Predicting soil erosion by water:A guide to conservation planning with the Revised Universal Soil Loss Equation (RUSLE). USDA Agricultural Handbook No 703. Washington DC: USDA.

Renewable Fuels Association. 2009a. Historic U.S. Fuel Ethanol Production. http://www.ethanolrfa. org/pages/statistics.

Renewable Fuels Association. 2009b. U.S. Ethanol Industry Biorefineries and Capacity. http://www.ethanolrfa. org/bio-refinery-locations/.

Sandretto, C., and J. Payne. 2006. Soil management and conservation. In Agricultural Resources and Environmental Indicators, 96-106. Economic Information Bulletin No. EIB-16. Washington DC: USDA Economic Research Service.

Schmer, M., K.Vogel, R. Mitchell, and R. Perrin. Net energy of cellulosic ethanol from switchgrass. Proceedings of the National Academy of Sciences 105(2008):464-469.

Searchinger, T., R. Heimlich, R.A. Houghton, F. Dong, A. Elobeid, J. Fabiosa, S. Tokgoz, D. Hayes, and T.Yu. 2008. Use of US croplands for biofuels increases greenhouse gases through emissions from land-use change. Science 319:1238-1240.

Sexton, S.E., D. Rajagopal, G. Hochman, D.W. RolandHolsts, and D. Zilberman. Biofuel: Distributional and Other Implications of Current and the Next Generation Technologies. 2008. In Risk, Infrastructure and Industry Evolution Proceedings of a conference, June 24-25, 2008, in Berkeley, CA, 12-22. Oak Brook, IL: Farm Foundation. http://www.farmfoundation.org/news/ articlefiles/365-Berkeley\%20proceedings.pdf.

Slinsky, S.P., D.E. Ray, and D.G. De La Torre Ugarte. 1996. The APAC budgeting system:A user's manual. Knoxville, TN: Agricultural Policy Analysis Center, The University of Tennessee.
Sperow, M. 2007. Marginal costs of carbon sequestration: Implications of one greenhouse gas mitigation activity. Journal of Soil and Water Conservation 62(6):367-375.

Sperow, M., M. Eve, and K. Paustian. 2003. Potential soil C sequestration on US agricultural soils. Climate Change 57:319-339.

Sugg, Z. 2007. Assessing U.S. farm drainage: Can GIS lead to better estimates of subsurface drainage extent? Washington DC: World Resources Institute. http://pdf. wri.org/assessing_farm_drainage.pdf.

US Congress. 2007. Energy independence and security act of 2007. Public Law No: 110-140. Washington DC: US Congress. http://frwebgate.access.gpo.gov/cgi-bin/ getdoc.cgi .dbname=110_cong_bills\&docid=f: h6enr. txt.pdf.

US DOE EIA (US Department of Energy Information Agency).2008.TableA17.Renewable energy, consumption by sector and source. Washington, DC: US Department of Energy Energy Information Administration. http://www. eia.doe.gov/oiaf/aeo/pdf/appa.pdf.

USDA ERS (Economic Research Service). 2000. Farm Resource Regions. Agricultural Information Bulletin 760. Washington DC: USDA Economic Research Service. http://www.ers.usda.gov/db/baseline/default. asp?ERSTab=3.

USDA ERS. 2007. Agricultural baseline data set. Washington DC: USDA Economic Research Service. http://www. ers.usda.gov/ db/baseline/default.asp?ERSTab=3.

USDA NASS (National Agricultural Statistics Service). 2004. 2002 Census of Agriculture. Washington DC: USDA National Agricultural Statistics Service. http://www. agcensus.usda.gov/.

USDA NASS. 2007. Data and statistics. Washington, DC: USDA National Agricultural Statistics Service. http:// www.nass.usda.gov/Data_and_Statistics/Quick_Stats_ $1.0 /$ index.asp.

USDA NRCS (Natural Resources Conservation Service). 1994. State Soil Geographic (STATSGO) Data BaseData Use Information. Misc. Publ. No. 1492. Washington DC: USDA Natural Resource Conservation Service.

USDA NRCS. 2007a. National resources inventory. Washington DC:USDA Natural Resources Conservation Service. 1997 and 2003 Data sets on CD. http://www. nrcs.usda.gov/technical/NRI/.

USDA NRCS. 2007b. Watersheds, hydrologic units, hydrologic unit codes, watershed approach, and rapid watershed assessments. Washington DC: USDA Natural Resources Conservation Service. http://www.nrcs. usda.gov/programs/rwa/Watershed_HU_HUC_ WatershedApproach_defined_6-18-07.pdf.

USGS (US Geological Survey). 1999. The Quality of Our Nation's Waters: Nutrients and Pesticides. US 
Geological Survey Circular 1225. Washington DC: US Geological Survey.

Vogelmann, J.E., S.M Howard, L.M. Yang, C.R. Larson, B.K. Wylie, and N.Van Driel. 2001. Completion of the 1990s national land cover data set for the conterminous United States from landsat thematic mapper data and ancillary data sources. Photogrammetric Engineering and Remote Sensing 67:650-662.

Weigel, J.C., D. Loy, and L. Kilmer. 1997. Feed co-products of the dry corn dry milling process: Featuring distillers dried grains. Des Moines, IA: Iowa Department of Agriculture and Land Stewardship, Iowa Corn Growers Association, Renewable Fuels Association, National Corn Growers Association. http://www.dakotagold. org/files/dry-milling-book.pdf.

Weimar, M.R., and R.P. Stillman. 1990. A long term forecasting model of the livestock and poultry sectors. Proceedings of the NCR-134 Conference on Applied Commodity Price Analysis, Forecasting, and Market Risk Management.

West, T.O., C.C. Brandt, B.W. Wilson, C.M. Hellwinckel, D.D. Tyler, D.G.G. Marland, De La Torre Ugarte, J.A. Larson, M. Mueller, and R. Nelson. 2008. Estimating regional changes in soil carbon with high spatial resolution: Integrating field measurements, inventory data, and remote sensing products. Soil Science Society of American Journal 72:285-294.

West, T.O., and G. Marland. 2002. A synthesis of carbon sequestration, carbon emissions, and net carbon flux in agriculture. Agriculture, Ecosystems, and Environment 91:217-232.

West, T.O., G. Marland, A.W. King, W.M. Post, A.K. Jain, and K. Andrasko. 2004. Carbon management response curves: Estimates of temporal soil carbon dynamics. Environmental Management 33:507-518.

West, T.O., and W.M. Post. 2002. Soil organic carbon sequestration rates by tillage and crop rotation: a global analysis. Soil Science Society of America Journal 66:1930-1946.

Williams, J.R., and H.D. Berndt. 1977. Sediment yield prediction based on water hydrology. Transactions of the American Society of Agricultural Engineers 20:1100-1104.

Wischmeier, W.H., and D.D. Smith. 1965. Predicting rainfall erosion losses from cropland east of the rocky mountains. Agricultural Handbook No. 282. Washington DC: USDA.

Wischmeier, W.H., and D.D. Smith. 1978. Predicting rainfall erosion losses - a guide to conservation planning. Agriculture Handbook No. 537. Washington DC: USDA Science and Education Administration. 